Research article

\title{
New species and new records of Graphis (Ostropales: Graphidaceae) from Eastern Ghats, India
}

\author{
Satish Mohabe ${ }^{1}$, Anjali Devi B. ${ }^{1}$, Sanjeeva Nayaka ${ }^{2}$ and A. Madhusudhana Reddy ${ }^{1 *}$ \\ ${ }^{1}$ Department of Botany, Yogi Vemana University, Vemanapuram, Kadapa-526003, Andhra Pradesh, India \\ ${ }^{2}$ Lichenology Laboratory, CSIR-National Botanical Research Institute, Rana Pratap Marg, \\ Lucknow-226001, Uttar Pradesh, India
}

*Corresponding Author: grassced@yahoo.com

[Accepted: 25 November 2016]

\begin{abstract}
A new species Graphis neeladriensis, and two new records, G. plumierae and G. subalbostriata are described from the Eastern Ghats of India. The newly described species is characterized by crustose, UV+ yellow thallus, sub-immersed to erumpent, short to elongate and simple to sparingly branched lirellae, 2-4 striate labia, laterally carbonized exciple, clear hymenium and terminally muriform ascospores.
\end{abstract}

Keywords: Rayalaseema - Seshachalam Biosphere Reserve - Lichens - Taxonomy.

[Cite as: Mohabe S, Anjali DB, Nayaka S \& Reddy AM (2016) New species and new records of Graphis (Ostropales: Graphidaceae) from Eastern Ghats, India. Tropical Plant Research 3(3): 611-615]

\section{INTRODUCTION}

Recent studies on the global diversity within the lichen family Graphidaceae indicates that there are large numbers of undiscovered species in the family and at least 175 species have been discovered since 2002. Further analysis predicts that geographically Graphidaceae have a concentrated diversity in a few regions of the world including Southern India (Lücking et al. 2014). Graphis Staiger (2002) is a major genus under the lichen family Graphidaceae, comprising of around 370 species worldwide (Kirk et. al. 2008, Lucking 2009, Joshi et al. 2010, Bárcenas-Peñta et al. 2014, Singh et al. 2014, Joshi et al. 2014). 111 species of Graphis are known from tropical, subtropical and temperate regions of India (Singh \& Sinha 2010) and recent studies added 17 more species to the genus (Chitale et al. 2011, Singh \& Swanlatha 2011a,b, Gupta \& Sinha 2012, Singh et al. 2014). Within the genus Graphis species having lichexanthone are rare and so far only five species such as G. stipitata A. W. Archer, G. sauroidea Leight., G. haleana R. C. Harris, G. lucifica R. C. Harris and G. flavopalmicola Y. Joshi, Lücking \& Hur are reported (Lücking 2009, Joshi et al. 2010).

During the exploration on lichen in Rayalaseema forest of Andhra Pradesh a total of 126 species have been reported (Reddy et al. 2011, Nayaka et al. 2013, Anjali et al. 2013, Mohabe et al. 2014a,b \& 2016) out of which only a single species Diorygma junghuhnii (Mont. \& Bosch) Kalb, Staiger \& Elix belonged to Graphidaceae. The explorations resulted in collection of several interesting specimens belonging to Graphidaceous taxa of which recently Mohabe et al. (2015a) described a new species Diorygma kurnoolensis Mohabe, Nayaka \& Reddy. In the present communication a new species Graphis neeladriensis and new records for India, $G$. plumierae Vain. and G. subalbostriata Lücking are reported. The new species is unique in having lichexanthone in chemistry and terminally muriform ascospores.

\section{MATERIALS \& METHODS}

The present study is based on recently collected specimens from Neeladri range of Tirumala hills (Fig. 1A) and Mallaiah Konda hills of Thambalapalli from Chittoor district which comes under Seshachalam Biosphere Reserve in Andhra Pradesh of India. The external morphology of the specimens were observed under a Magnüs MS 24/13 stereo-zoom microscope while anatomical characters of the thallus and apothecia were observed under a ZEISS Axiostar plus compound microscope. Thin hand cut sections of the thallus and apothecia were initially mounted in water to record the colour and measurements of various structures. The apothecial sections were then observed after applying aqueous $10 \% \mathrm{KOH}$ solution while Lugol's solution (I) was used for iodine 
reactions. The colour tests were performed by using routine reagents; aqueous solution of $\mathrm{KOH}(\mathrm{K})$, calcium hypochlorite (C), and paraphenylenediamine (P). The lichen substances were identified by thin-layer chromatography following literature (White \& James 1985, Orange et. al. 2001) and specimens were identified through world key to the genus Graphis (Lücking et al. 2009) and by comparison with the protologues. The nomenclature of Lücking et al. (2009) was followed for lirellae morphology. The specimens of the new species have been deposited in the Herbarium of CSIR-National Botanical Research Institute Lucknow (LWG), Uttar Pradesh, India and specimens of new records have been deposited in the Lichen Herbarium, Department of Botany, Yogi Vemana University (YVUH) Kadapa, Andhra Pradesh, India.

\section{RESULTS \& DISCUSSION}

NEW SPECIES

Graphis neeladriensis Mohabe S, Anjali DB \& Nayaka S sp. nov.

(Fig. 1A-F)

MycoBank No.: MB 819499

This species is characterized by sub-immersed to erumpent, short to elongate and simple to branched lirellae, 2-4 striate labia, laterally carbonized exciple, clear hymenium, 8-spored ascus, transversely 4-12 and terminally 1-2(-3) vertically septate ascospores and presence of lichexanthone in thallus.

Type: INDIA, Andhra Pradesh, Chittoor district, Tirumala hills, Neeladri range, on bark of Artocarpus heterophyllus, alt. ca. 650 m, 06.07.2014, Satish Mohabe \& Anjali Devi B. 4097 (holotype-LWG).

Thallus greenish grey to grey, smooth to cracked, shiny, 80-160 $\mu \mathrm{m}$ thick, corticated; cortex hyaline, 20-35 $\mu \mathrm{m}$ thick; algal layer continuous $75-120 \mu \mathrm{m}$ thick, medulla with oxalate crystals, $10-25 \mu \mathrm{m}$ thick; prothallus indistinct or white.

Ascomata lirellate, variable, numerous, sub-immersed to erumpent, simple, short to elongate (towards centre) and sparingly branched (towards periphery), 0.2-3.5 mm long, 0.1-0.4 mm wide, end acute to obtuse, laterally covered by thalline margin in younger parts; labia epruinose, 2-4 striate; disc slit like closed, rarely open, epruinose; exciple dark brown to black, 50-90 $\mu \mathrm{m}$ thick, convergent, laterally carbonized; hymenium hyaline, clear, without oil globules, 175-225 $\mu \mathrm{m}$ wide, 85-200 $\mu \mathrm{m}$ high; hypothecium hyaline; ascus cylindrical, 40-150 $\times$ 14-20 $\mu \mathrm{m}, 8$-spored, I-; ascospores hyaline, transversely 4-12 and vertical cells 1-3 in end locules (terminally muriform), 24-77 × 7-12 $\mu \mathrm{m}$, I+ blue.

Table 1. Comparison of Graphis species containing lichexanthone. (New species is in bold)

\begin{tabular}{|c|c|c|c|c|c|c|c|c|}
\hline Species name & Lirellae morph & Labia & Exciple & Hyme & Septation & No. of septa & Spore length & Substance \\
\hline $\begin{array}{l}\text { 1. Graphis } \\
\text { flavopalmicola }\end{array}$ & handelii-morph & entire & $\begin{array}{l}\text { completely } \\
\text { carbonized }\end{array}$ & clear & $\begin{array}{l}\text { transversely } \\
\text { septate }\end{array}$ & 5-9-septate & $19-27 \mu \mathrm{m}$ & Unknown \\
\hline 3. Graphis lucifica & striatula-morph & striate & $\begin{array}{l}\text { completely } \\
\text { carbonized }\end{array}$ & clear & $\begin{array}{l}\text { transversely } \\
\text { septate }\end{array}$ & 5-9-septate & $20-40 \mu \mathrm{m}$ & Nil \\
\hline $\begin{array}{l}\text { 5. Graphis } \\
\text { sauroidea }\end{array}$ & hossei-morph & entire & $\begin{array}{l}\text { completely } \\
\text { carbonized }\end{array}$ & clear & $\begin{array}{l}\text { transversely } \\
\text { septate }\end{array}$ & 4-5-septate & $45-60 \mu \mathrm{m}$ & Nil \\
\hline $\begin{array}{l}\text { 6. Graphis } \\
\text { stipitata }\end{array}$ & hossei-morph & entire & $\begin{array}{l}\text { laterally } \\
\text { carbonized }\end{array}$ & clear & $\begin{array}{l}\text { transversely } \\
\text { septate }\end{array}$ & 7-15-septate & $15-20 \mu \mathrm{m}$ & $\begin{array}{l}\text { Norstictic, } \\
\text { connorstictic } \\
\text { acid }\end{array}$ \\
\hline
\end{tabular}

Chemistry: Thallus $\mathrm{K}-$, $\mathrm{P}-$, $\mathrm{C}-$, KC- , UV+ yellow; TLC: lichexanthone present.

Distribution and Ecology: Graphis neeladriensis is found growing on bark of Arctocarpous heterophylla trees growing in the In-situ conservation garden of medicinal plants in Neeladri range of Tirumala hills, Chittoor district of Andhra Pradesh at an altitude of around $650 \mathrm{~m}$. It was found growing in association with other crustose lichens such as Bacidia sp., Graphis sp., Lecanora achroa Nyl. and a foliose species Hyperphyscia adglutinata (Flörke) H. Mayrhofer \& Poelt.

Etymology: The specific epithet is named after type locality Neeladri range which is the highest peak of Tirumala hills.

www.tropicalplantresearch.com 

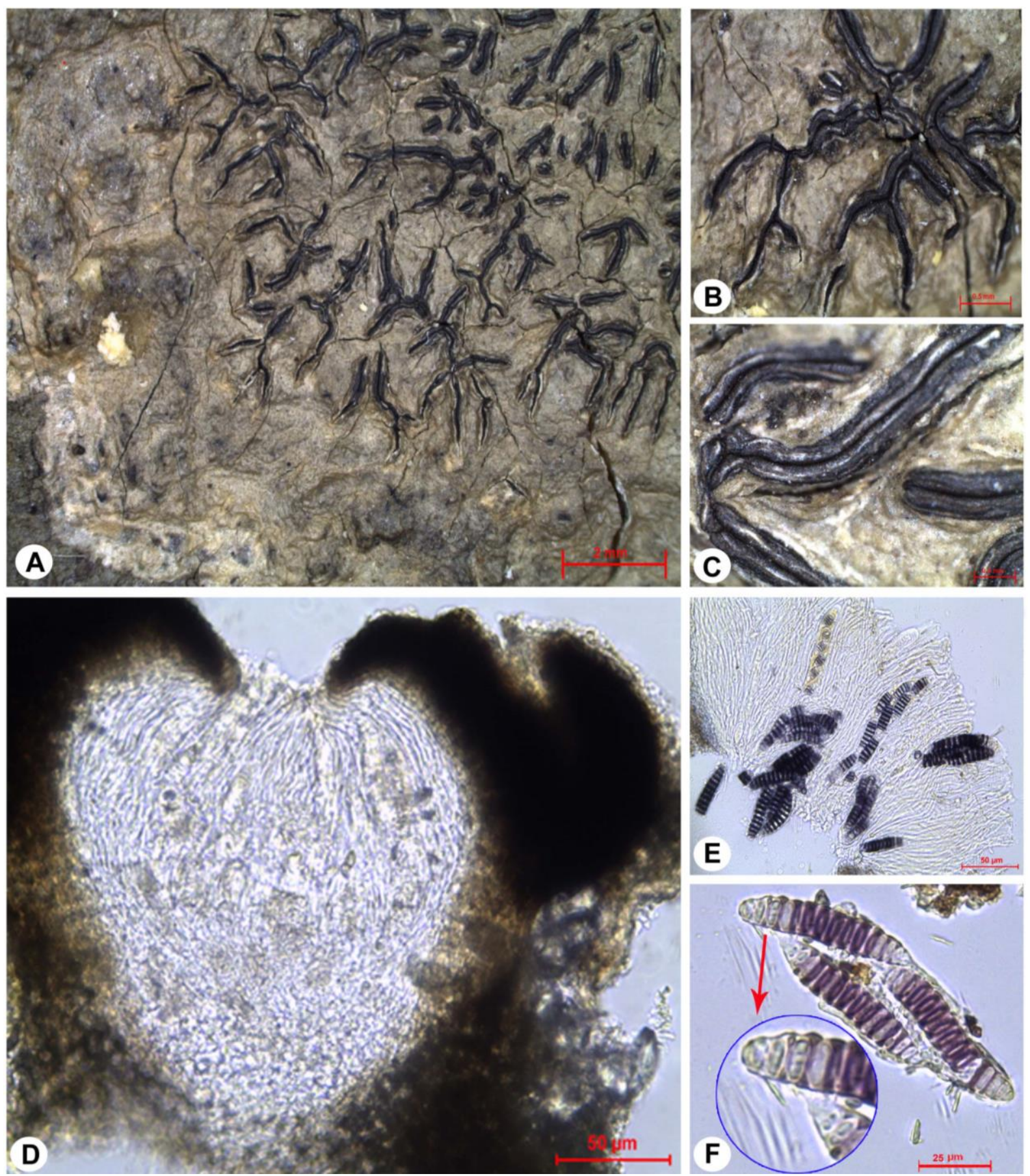

Figure 1. Graphis neeladriensis (holotype): A-C, Habit showing variations in lirellae; D, transverse section of lirellae; E, ascus with ascospores; $\mathbf{F}$, terminally muriform ascospores in iodine.

Remark: Graphis neeladriensis resembles Graphis neoelongata Lücking and Graphis dichotoma (Müll. Arg.) Lücking in having striate labia, laterally carbonized exciple, clear hymenium, terminally muriform or submuriform ascospores but both the species differs chemically by lacking lichexanthone in thallus. The lichexanthone containing species, G. haleana, and G. lucifica differs from new species with completely carbonized exciple and transversely septate ascospores, while G. stipitata differs in having entire labia, smaller ascospores and presence of norstictic and connorstictic acid. Further G. flavopalmicola and G. sauroidea have entire labia, completely carbonized exciple, transversely septate and smaller to medium ascospores. The comparative status of the new species among other lichexanthone containing species are given in table 1.

Additional specimen examined: INDIA, Andhra Pradesh, Chittoor district, Tirumala hills, Neeladri range, on bark of Artocarpus heterophyllus, alt. ca. 650 m, 06.07.2014, Satish Mohabe \& Anjali Devi B. 4098 (isotypeLWG). 


\section{NEW RECORDS}

1. Graphis plumierae Vain. Ann. Acad. Sci. fenn., Ser. A 6(7): 161 (1915).

(Fig. 2A)

Thallus whitish to greenish grey, smooth to cracked, corticated, 190-297 $\mu \mathrm{m}$ thick; cortex hyaline, 23-39 $\mu \mathrm{m}$ thick; medulla white with many crystals, 10-28 $\mu \mathrm{m}$ wide; algal layer continuous 75-95 $\mu \mathrm{m}$ thick; prothallus indistinct to brownish.

Apothecia lirellate, numerous, immersed to sub-immersed, simple to branched, 1.0-2.5 mm long, 0.3-0.7 $\mathrm{mm}$ wide, with rounded to acute ends; labia pruinose, laterally covered by thalline margin; disc concealed, epruinose; epihymenium 14-19 $\mu \mathrm{m}$, exciple dark brown to black, laterally carbonized, 25-62 $\mu \mathrm{m}$ thick; hymenium inspersed, with oil globules, 122-149 $\mu \mathrm{m}$ wide; hypothecium hyaline to yellowish brown 20-36 $\mu \mathrm{m}$ high; ascus cylindrical, 64-100 × 9-16 $\mu \mathrm{m}, 8$-spored; ascospores colourless, transversely 5-11 septate, 18-58 $\times$ 6-10 $\mu \mathrm{m}$.

Chemistry: $\mathrm{K}+$ yellow turning red, $\mathrm{P}+$ yellow, $\mathrm{KC}-, \mathrm{C}-$; TLC: Norstictic acid, stictic and salazinic acid present.

Distribution: It is a Neotropical species earlier known from Guadeloupe, Mexico and in the present study it is found on tree trunks in tropical forests of Eastern Ghats in India.

Remark: G. plumierae Vain. has resemblance to G. brevicarpa M. Nakan., Kashiw. \& K.H. Moon and $G$. crebra but differs by its concealed disc, white pruinose labia, immersed lirellae with lateral thalline margin and presence of norstictic acid with stictic and salazinic acid. Further G. brevicarpa differs by its apically thick complete thalline margin, epruinose labia and smaller ascospores while G. crebra has erumpent lirellae with lateral thalline margin, exposed disc with white pruina (scripta-morph).

Specimens examined: INDIA, Andhra Pradesh, Chittoor district, Thambalapalli, Mallaiah Konda Hills, alt. $c a$. 956 m, on bark, 05.01.2013, A. Madhusudhana Reddy \& Satish Mohabe 2812 (LWG); Tirumala hills, Dharmagiri, alt. ca. 937 m, on bark, 07.02.2013, Anjali Devi B. \& Satish Mohabe 3414 (YVUH).
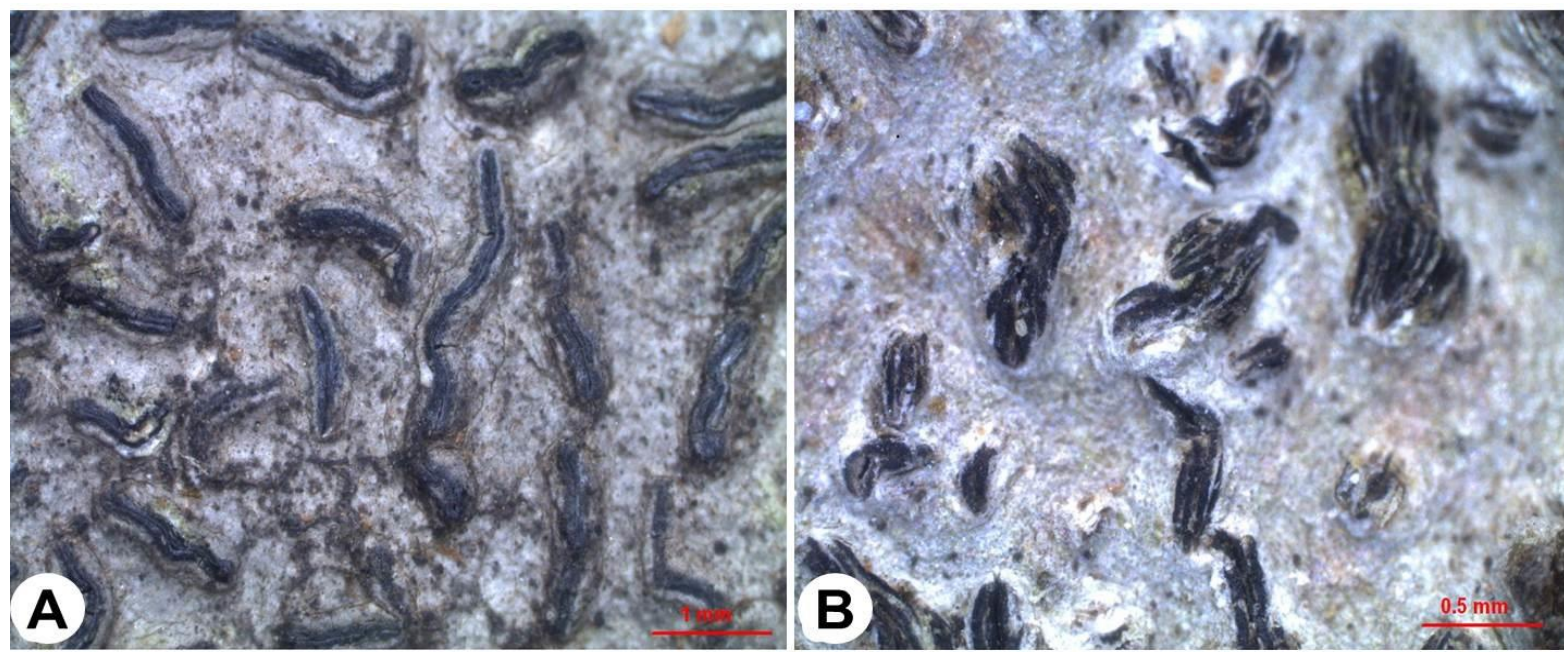

Figure 2. Habit of Graphis species A, Graphis plumierae Vain.; B, Graphis subalbostriata Lücking.

2. Graphis subalbostriata Lücking, Lichenologist 41(4): 363-452 (2009).

(Fig. 2B)

Thallus crustose, corticolous, whitish grey, thin, shiny, smooth to rough, continuous to discontinuous ecorticated; prothallus indistinct or absent.

Apothecia lirellate, lirellae simple, small, rarely branched, $0.5-1.5 \mathrm{~mm}$ long, $0.1-0.5 \mathrm{~mm}$ wide, erumpent to prominent, laterally covered by thallus; disc concealed, epruinose; labia partially black, with 7-8 striation, distinct white lines in-between striation, formed by clusters of calcium-oxalate crystals; exciple apically to peripherally carbonized, 21-27 $\mu \mathrm{m}$ thick; hymenium clear, without oil globules; ascus cylindrical, 125-235 $\times$ 20-30 $\mu \mathrm{m}, 8$-spored; ascospores colourless, fusiform, transversely 5-11-septate, 45-95 × 8-12 $\mu \mathrm{m}$.

Chemistry: Thallus $\mathrm{K}-, \mathrm{KC}-, \mathrm{C}-, \mathrm{P}-$; TLC: No chemicals.

Distribution: It is a Neotropical species earlier recorded from Guadeloupe and in the present study it was found on tree trunks in tropical forest of Eastern Ghats in India.

Remark: $G$. subalbostriata is close to $G$. patwardhanii Kulk. but latter species has isidiate thallus. $G$. subalbostriata is also close to G. olivacea but it has dark olive-grey thallus, erumpent lirellae with apically thin and complete thalline margin, elongate and irregularly branched lirellae.

www.tropicalplantresearch.com 
Specimen examined: INDIA, Andhra Pradesh, Chittoor district, Tirumala hills, Dharmagiri, on bark, alt. $c a$. 937 m, 07.02.2013, Anjali Devi B. \& Satish Mohabe 3396, 3449, 3402, 3420 (YVUH); Shilathoranam, on bark, alt. ca. 958 m, 05.07.2013, Satish Mohabe \& Anjali Devi B. 4034 (YVUH).

\section{ACKNOWLEDGMENTS}

The authors are very grateful to Council of Scientific and Industrial Research, New Delhi and Department of Science and Technology (INSPIRE), New Delhi for financial support; to the Director and Dr. D.K. Upreti, Chief Scientist, CSIR-National Botanical Research Institute, Lucknow for providing laboratory facilities; to Forest Officials of Andhra Pradesh for their cooperation during the exploration.

\section{REFERENCES}

Bárcenas-Peñta A, Lücking R, Miranda-González R \& Herrera-Campos MA (2014) Three new species of Graphis (Ascomycota: Ostropales: Graphidaceae) from Mexico, with updates to taxonomic key entries for 41 species described between 2009 and 2013. Lichenologist 46: 69-82.

Chitale G, Makhija U \& Sharma B (2011) Additional species of Graphis from Maharashtra, India. Mycotaxon 115: 469-480.

Gupta P \& Sinha GP (2012) A new record of lichen in the genus Graphis for India from Assam. Indian Journal of Forestry 35(1): 133-134.

Joshi S, Jayalal U, Oh SO, Nguyen TT, Dzung NA \& Hur JS (2014) A New Species of Graphis and New Lichen Records from Vietnam, Including a Second Worldwide Report of Sarcographina cyclospora. Mycobiology 42(1): 17-21.

Joshi Y, Lücking R, Yamamoto Y, Wang XY, Jin KY \& Hur JS (2010) A new species of Graphis (lichenized Ascomycetes) from South Korea. Mycotaxon 113: 305-309.

Lücking R (2009) The taxonomy of the genus Graphis sensu Staiger: (Ostrapales: Graphidaceae). Lichenologist 41: 319-362.

Lücking R, Archer AW \& Aptroot A (2009) A worldwide key to the genus Graphis (Ostropales: Graphidaceae). Lichenologist 41: 363-452.

Lücking R, Mark K, Johnston, Aptroot A et al. (2014) One hundred and seventy-five new species of Graphidaceae: closing the gap or a drop in the bucket? Phytotaxa 189 (1): 007-038.

Mohabe S, Nayaka S, Reddy MA \& Anjali DB (2015a) Diorygma kurnoolensis (Graphidaceae), a new species of saxicolous lichen from Southern India. Geophytology 45(1): 47-50.

Mohabe S, Reddy MA, Anjali DB, Nayaka S \& Chandramati PS (2014a) Further new addition to the lichen mycota of Andhra Pradesh, India. Journal of Threatened Taxa 6(8): 6122-6126.

Mohabe S, Reddy MA, Anjali DB Nayaka S \& Chandramati PS (2014b) Assessment of lichens diversity in Rayalaseema Forest of Andhra Pradesh, India. In: National Conference on Plant Biology-2014. held at Department of Botany, Yogi Vemana University, Vemanapuram, Kadapa, Andhra Pradesh. pp. 50-51.

Mohabe S, Anjali DB, Reddy AM, Nayaka S \& Chandramati PS (2016) An appraisal of lichen biota in Chittoor district of Andhra Pradesh, India. In: Pulaiah T, Sandhya R (eds) Biodiversity in India. pp. 247-296.

Nayaka S, Reddy MA, Ponmurugan P, Devi BA, Ayyappadasan G \& Upreti DK (2013) Eastern Ghats, biodiversity reserves with unexplored lichen wealth. Current Science 104(7): 821-825.

Orange A, James PW \& White FJ (2001) Microchemical methods for the identification of lichens. British Lichen Society, U.K.

Reddy MA, Nayaka S, Shankar PC, Reddy SR \& Rao BRP (2011) New distributional records and checklist of lichens for Andhra Pradesh, India. The Indian Forester 137: 1371-1376.

Singh KP \& Swarnlatha G (2011a) New records of Graphis (Lichenized fungi) from India. Indian Journal of Forestry 34: 243-244.

Singh KP \& Swarnlatha G (2011b) A note on Graphidaceous lichens from Arunachal Pradesh, India. Indian Journal of Forestry 34: 353-360.

Singh P \& Singh KP (2014) Two new species of Graphis (Ascomycota: Ostropales: Graphidaceae), from Indo-Burma biodiversity hotspot. Mycosphere 5(4): 504-509.

Staiger B (2002) Die Flechtenfamilie Graphidaceae: Studien in Richtung einer natürlicheren Gliederung. Bibliotheca Lichenologica 85: 1-526.

White FJ \& James PW (1985) A new guide to microchemical techniques for the identification of lichen substances. Bulletin British Lichen Society 57(Suppl.): 1-41. 